\title{
METHODOLOGICAL BASIS IMPROVING EFFICIENCY FORMATION OF COGNITIVE INDEPENDENCE OF MEDICAL STUDENTS IN THE STUDY OF MEDICAL AND BIOLOGICAL PHYSICS
}

\author{
МЕТОДОЛОГІЧНІ ОСНОВИ ПІДВИЩЕННЯ \\ ЕФЕКТИВНОСТІ ФОРМУВАННЯ ПІЗНАВАЛЬНОЇ \\ САМОСТІЙНОСТІ СТУДЕНТІВ-МЕДИКІВ ПРИ ВИВЧЕННІ \\ МЕДИЧНОЇ ТА БІОЛОГІЧНОЇ ФІЗИКИ
}

Tatyana TOCHILINA, Candidate of Pedagogical Sciences, кандидат педагогічних наук, доцент Associate Professor

https://orcid.org/0000-0002-4886-9720 toch2008mail.ru@gmail.com

Zaporizhzhya State Medical University street Mayakovsky,26. Zaporizhzhya, 69036
Запорізький державний медичний університет вул.. Маяковського, 26 м.Запоріжжя, 69036

Original manuscript received: October 14, 2019

Revised manuscript accepted: December 09, 2019

\section{ABSTRACT}

In the proposed article the notion of "cognitive independence of the student» and structure of cognitive independence are analyzed. There have been defined organizational and pedagogical conditions of effective development of cognitive independence of students and factors, under which it is performed.

Key words: autonomy, cognition, cognitive independence of the student, the structure of cognitive independence, organizational and pedagogical conditions of effective development of cognitive independence.

Постановка проблеми. Основу курсу "Медична та біологічна фізика" (МіБФ) складають розділи прикладної фрізики, які покликані вирішити медичні завдання, питання біофізики (біофізика мембран, біофізика клітин і органів, біофізика складних систем) та деякі технічні питання (медична апаратура, медична електроніка, дозиметрія іонізуючих випромінювань). Метою курсу МіБФ є здобуття студентами фрізико-технічних і біофрізичних знань і формування умінь, які необхідні як для навчання інших навчальних дисциплін медичного закладу вищої освіти, так і для безпосереднього становлення особистості лікаря.

Досвід роботи в медичному університеті вказує на те, що студенти не проявляють особливої пізнавальної самостійності, активності та творчості в навчанні. Викладач і підручники є основними джерелами 
знань. У результаті випускники не вміють самостійно засвоювати нові знання і творчо їх застосовувати, зазнають труднощів у ситуаціях, у яких повинні самостійно орієнтуватися й приймати оптимальне рішення. Тому виникла потреба в підвищенні ефективності формування та розвитку пізнавальної самостійності студента-медика, особистісно-орієнтованій системі освіти, коли студент і його діяльність є головною.

Аналіз останніх досліджень. Проблема формування і розвитку пізнавальної самостійності досліджена у роботах Л. Арістової, С. Архангельського, Ю. Бабанського, Л. Виготського, В. Давидова, М. Данілова, В. Загвязінського, Л. Занкова, І. Ільясова, І. Лернера, А. Матюшкина, М. Махмутова, П. Підкасистого, П. Самойленка, М. Скаткина, Г. Щукіної, Д. Ельконіна та ін.

Проблеми ефективності навчання розглянуті в роботах Ю. Бабанського, В. Блинова, Л. Вигоцького, Л. Колесникова, А. Леонтьєва, Г. Рябова, П. Самойленка та ін.

Аналіз педагогічної літератури, присвяченої проблемі підвищення ефективності формування пізнавальної самостійності студентів, показав, що єдиної думки про суть поняття “пізнавальна самостійність” до цих пір не існує. Автори досліджень вкладають різний сенс у зміст поняття “пізнавальна самостійність". Одні розглядають його як властивість особи, яка виявляється в прагненні власними силами оволодіти знаннями (Т. Шамова), інші мають на увазі інтелектуальні здібності учня та вміння, що дозволяють йому самостійно вчитися (М. Махмутов), треті готовність власними силами просуватися в оволодінні знаннями (Н. Половникова), четверті бачать у пізнавальній самостійності багатоаспектну особисту освіту (Г. Саранцев, М. Якунчев).

По-різному дослідниками визначено шляхи підвищення ефективності формування пізнавальної самостійності через організацію самостійної роботи (Б. Єсипов, М. Скаткін і ін.), формування прийомів пізнавальної діяльності (В. Давидов, Д. Ельконін), за допомогою введення у зміст навчання методологічних знань (В. Бєліков, І.Лернер, П. Підкасистий, А. Усова).

Аналіз літератури з проблеми розвитку пізнавальної самостійності вказує і на те, що більшість практичних методів, форм і засобів навчання у 3 ВО не $є$ ефективними та не дозволяють повною мірою забезпечити особистісно-орієнтований підхід у розвитку пізнавальної самостійності кожного студента. Це обумовлює необхідність виявлення таких ефективних підходів у викладанні, які сприяли б розвитку пізнавальної самостійності студентів.

Мета статті. Метою даної статті є уточнення поняття "пізнавальна самостійність студента" та її структури, а також визначення організаційнопедагогічних умов ефективного формування пізнавальної самостійності студентів-медиків і чинників, під впливом яких вона здійснюється.

Виклад основного матеріалу. На основі аналізу визначень “пізнавальної самостійності”, “самостійності”, “пізнання”, наданих різними авторами, ми виділили загальні характеристики поняття “пізнавальна 
самостійність". Це: потреба та бажання просуватися в оволодінні новими професійно-педагогічними знаннями і засобами дій, здійснювати проектування змісту свого навчання; прагнення та вміння учнів без сторонньої допомоги раціонально планувати, виконувати, контролювати та коригувати свою пізнавальну діяльність; використання на основі вольових зусиль способів і методів пізнавальної діяльності для вирішення будь-яких життєвих проблем;якість або властивість особистості.

Аналіз і узагальнення різних точок зору дозволяє нам дати таке визначення: пізнавальна самостійність - це вольова якість особи, яка виявляється через здатність людини ставити цілі, планувати й ефективно виконувати на певному рівні (змістовному та організаційному) дію або комплекс дій без зовнішньої допомоги.

Виділимо структурні компоненти пізнавальної самостійності. Це дозволить нам: 1) виявити, які 3 них мають вирішальну роль в її формуванні і розвитку;

2) встановити істотні умови; 3) спланувати спільну діяльність викладача та студента для досягнення найбільшого ефекту в розвитку пізнавальної самостійності студента.

Ми виділяємо п'ять найбільш істотних компонентів пізнавальної самостійності: мотиваційний, орієнтаційний, змістовно-операційний, емоційно-вольовий і оціних.

Структура пізнавальної самостійності представлена на рис. 1.

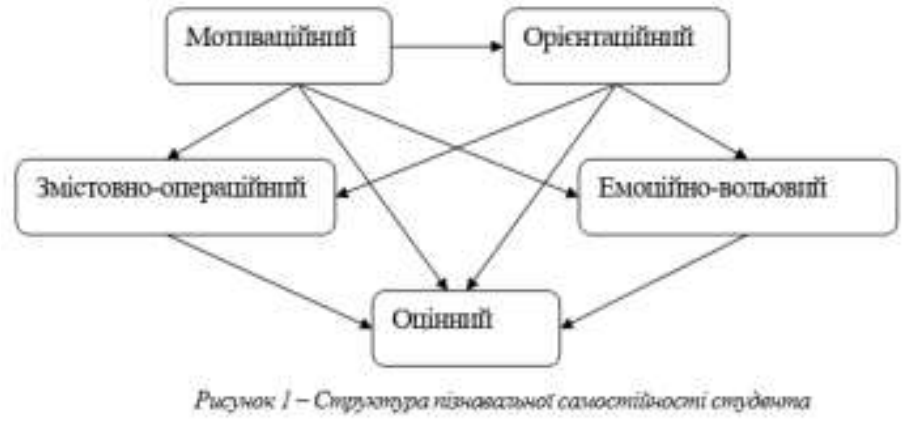

Першим компонентом пізнавальної самостійності є мотиваційний, який визначає інтерес студента до процесу пізнання.

Другий компонент - орієнтаційний. Він передбачає здатність і уміння студента ставити і досягати мети своєї пізнавальної діяльності, раціонально її планувати і прогнозувати для досягнення цілей. Володіння студентами системою опорних знань, методів, прийомів та способів пізнавальної діяльності входить до третього - змістовно-операційного компоненту. До опорних знань відносяться ті, що складають основу для набуття нових знань та узагальнень і $€$ головними в науці, яка вивчається. Самостійно засвоїти нові знання можна лише на основі вже наявних знань і умінь. Окрім володіння опорними знаннями, для прояву самостійності в навчанні обов'язково необхідно володіти методами, 
способами і прийомами розумової діяльності, які поділяються на три складники: інтелектуальні вміння, загальні навички праці й спеціальні вміння, характерні для конкретної науки. Таким чином, опорні знання й інтелектуальні вміння $€$ основою для здатності студента-медика до самостійного оволодіння знаннями.

Четвертий компонент пізнавальної самостійності - емоційновольовий. Для досягнення поставленої мети недостатньо лише прагнення, необхідно мати високу цілеспрямованість, володіти якостями волі, необхідними для подолання пізнавальних труднощів, такими, як рішучість, наполегливість, витримка, постійність. Позитивні емоції готують студента до діяльності, сприйняття навчального матеріалу, визначають пізнавальні дії.

П'ятий компонент пізнавальної самостійності - оціний. Він включає здатність та вміння студента оцінювати свої потенційні можливості при виконанні пізнавальної діяльності, та результати, коригувати свою пізнавальну діяльність.

Відмітимо, що всі компоненти пізнавальної самостійності взаємозв'язані, взаємообумовлені і в реальному освітньому процесі. За відсутності хоча б одного з цих компонентів зникає пізнавальна самостійність. Для того, щоб розвивати пізнавальну самостійність студентів-медиків у процесі викладання курсу медичної та біологічної фрізики, необхідно виявити чинники й умови, які впливають на розвиток цілі якості.

Чинники, під впливом яких здійснюється формування, і розвиток пізнавальної самостійності студентів, діляться на чотири групи:

1. Соціальні - вплив батьків, засобів масової інформації, спілкування з фахівцями, що працюють у певній галузі тощо.

2. Освітні - чинники, які визначають змістовність пізнавальної самостійності: уявлення, фракти, закони, теорії і методи науки, тобто опорні знання.

3. Психологічні - чинники, які обумовлені віковими особливостями студентів: свідома потреба у фрормуванні власних поглядів і переконань, в самовдосконаленні і самовизначенні в професії;

-вольовий чинник і чинники особистого характеру: схильності, здібності, рівень загальноосвітньої підготовки; спонукальні чинники, спрямовані на формування і розвиток внутрішніх спонукань, які направляють розум і відчуття на оволодіння знаннями власними силами: цікавість, допитливість, бажання краще підготуватися до майбутньої професії, прагнення до розумової діяльності, небажання мати погану оцінку з предмета тощо;

4. Процесуальні чинники, що впливають на формування i розвиток пізнавальної самостійності студентів: методи, прийоми і засоби роботи викладача зі студентами, форми проведення аудиторних i позааудиторних занять.

3 метою дослідження впливу різних чинників на розвиток пізнавальної самостійності нами було проведено тестування 155 
студентів першого курсу і 12 викладачів 3ВО. У ході проведеного дослідження нами були зроблені такі висновки (рис. 2). На перше місце серед чинників, що впливають на розвиток пізнавальної самостійності, студенти-медики ставлять процесуальні (67\%). Вони вважають, що багато в чому саме від викладача, від його форм і методів роботи із студентами залежить розвиток їхньої пізнавальної самостійності.

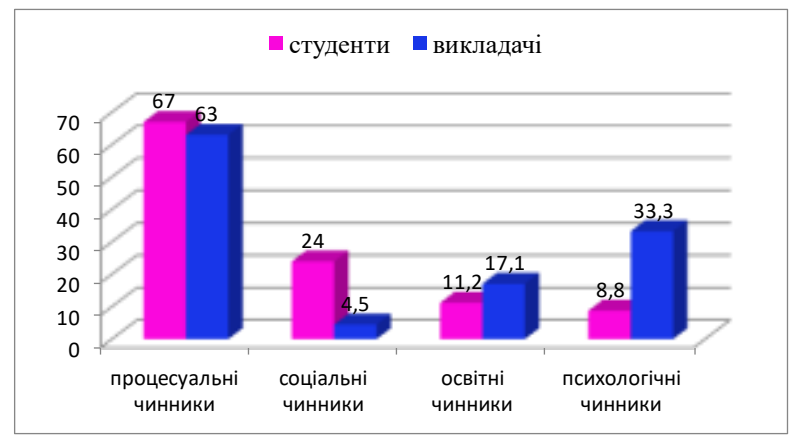

\section{Рис.2. Вплив різних чинників на розвиток пізнавальної самостійності студентів за оцінкою студентів та викладачів}

Незначний контингент студентів (15\%) серед цієї групи чинників вказали експериментальні завдання, як стимул до пізнавальної активності і самостійності, що вказує на бажання займатися науковим експериментом навіть у рамках аудиторії. Невеликий відсоток студентів $(10,9 \%)$ серед процесуальних чинників, які впливають на пізнавальну самостійність, вказали проблемний виклад матеріалу. Незначна кількість респондентів, оскільки викладачі рідко на заняттях застосовують елементи проблемного навчання, пояснюючи це тривалою підготовкою.

На другому місці серед груп чинників пізнавальної самостійності студентів знаходяться соціальні (24\%), а саме: роль батьків $(19 \%) ;$ засоби масової інформації (4\%) та знайомства з фахівцями, які працюють у певній галузі (5\%). Щодо батьків студенти мали на увазі не лише їх контроль та стимулювання, але і роль у виборі майбутньої професії. Сучасні засоби масової інформації (радіо, телебачення, IHTEPHЕT) володіють величезними можливостями щодо виховання й освіти молоді, але, на жаль, вони багато в чому втрачають виховне і повчальне значення, перетворюючись, головним чином, у розважальні засоби, тому студенти і відвели їм таку незначну роль у розвитку пізнавальної самостійності. Відмічені студентами знайомства з фахівцями, що працюють у певній галузі, дійсно впливають на розвиток пізнавальної самостійності майбутніх медиків, оскільки вони можуть почути про нюанси своєї майбутньої професії, урозуміти цю необхідності здобуття певних знань для подальшої роботи, що й стимулює їх до пізнавальної самостійності.

Третє місце серед чинників, які впливають на розвиток пізнавальної самостійності, відвели освітнім чинникам (11,2 \%), які включають фракти, закони і методи науки. Зміст навчання знайомить студентів з об'єктивними 
науковими фрактами, теоріями, законами і відображає сучасний стан науки. Це втілюється в навчальних програмах і підручниках, відбір теоретичного матеріалу, а також у здатності наукового пошуку, методів дослідження, способів організації освітнього процесу. Вивчення теорій, законів, і методів науки спрямовує педагога на використання в організації освітньої діяльності проблемних ситуацій, спостережень явищ і процесів, наукових дискусій, пошук додаткової наукової інформації тощо, це все розвиває пізнавальну самостійність студентів.

Четверте місце в розвитку пізнавальної самостійності, за оцінкою студентів, займає група психологічних чинників (8,8\%); де найбільший відсоток $(24,4 \%)$ відведено бажанню краще підготуватися до своєї майбутньої професії. Це вказує на розуміння з боку студентів того, що простої суми знань для подальшої професійної діяльності недостатньо. Досить незначним $є$ інтерес до предмета і знань взагалі (5,9\%). Це можна пояснити тим, що інтерес до навчання викликаний необхідністю скласти залік або екзамен, отримати гарну оцінку.

3 чинником інтересу до навчання медичної та біологічної фізики тісно зв'язані цікавість і допитливість, що зазначили (3,3\%) респондентів. Тому викладач повинен викликати інтерес до предмета, стимулювати цікавість студента, яка підштовхуватиме його до пізнавальної самостійності. Так само в цій групі чинників вказуються схильності та здібності $(7,2 \%)$, оскільки якщо педагог їх розвиватиме, із студента може вийти добрий фахівець.

Окрім вищеперелічених чинників, студенти вказали ще деякі, стимулюють розвиток їхньої пізнавальної самостійності (4\%), такі як: моральна педагогічна підтримка (у вигляді похвали, високої оцінки і т. д.) студента, який проявив пізнавальну активність; гуманістичний підхід педагога В організації освітнього процесу, який передбачає самовизначення, самоорганізацію, творчість, свободу, вибір, альтернативність, взаємодію; надання студентам індивідуальних домашніх завдань, що вимагають якісної самостійної підготовки.

Проаналізуємо результати анкетування, проведеного серед викладачів (рис. 2). Головним чинником розвитку пізнавальної самостійності педагоги вважають форми і методи роботи із студентами, тобто викладачі визнають провідну роль у розвитку пізнавальної самостійності студентів процесуальних чинників (62,9\%). Оцінка педагогами цієї групи близька з оцінкою студентів, оскільки вони $є$ учасниками одного освітнього процесу і реально можуть оцінити вплив певного чинника на розвиток пізнавальної самостійності майбутніх медиків. Серйозне значення в розвитку пізнавальної самостійності викладачі відводять проблемному викладу матеріалу i експериментальним завданням (18,3 і $17,6 \%$ відповідно), що так само відповідає думці студентів (13,9 і 15\% відповідно).

Викладачі розуміють важливість і психологічних чинників при розвитку пізнавальної самостійності (33,3\%), велику роль у цій групі вони відводять бажанню студентів краще підготуватися до майбутньої 
профресії (20\%), а потім вже інтересу до предмета і знань взагалі (5\%), схильностям і здібностям (4,6\%), цікавості й допитливості $(3,7 \%)$. Відзначимо, що студенти цій групі чинників віддали лише четверте місце.

Третю позицію серед чинників, за оцінкою викладачів, займають освітні чинники $(17,1 \%)$, тобто уявлення, закони, факти, теорії і методи науки. На наступній позиції знаходяться інші чинники пізнавальної самостійності (7,2\%), наприклад: проведення нетрадиційних фрорм перевірки знань студентів; можливість студентам навчатися за індивідуальною програмою, обирати освітню траєкторію тощо.

Потім викладачі відзначають роль соціальних чинників $(4,5 \%)$ при розвитку пізнавальної самостійності студентів. Таким чином, дослідження показують, що і студенти, і викладачі віддають провідну роль у розвитку пізнавальної самостійності процесуальним чинникам. У той же час у них $\epsilon$ специфічні погляди на роль різних чинників при розвитку пізнавальної самостійності.

До педагогічних умов ефективного розвитку пізнавальної самостійності студентів у процесі вивчення фрізики у вищій технічній школі ми відносимо:

1. Активна участь студентів у навчанні - прагнення до ефективного оволодіння знаннями та засобами діяльності, мобілізація вольових зусиль для досягнення навчально-пізнавальних цілей.

2. Використання комплексу розвивального методів: а) інформаційні методи;

б) спрямованих на передачу студентам нових знань і зв'язків між ними: (лекції, консультації, семінари, колоквіуми, іспити); в) операційні методи, призначені для формування вмінь і навичок дії в типових ситуаціях: лабораторні і практичні роботи; г) пошукові методи застосовуються для фрормування і розвитку вмінь і навичок конкретної продуктивної діяльності в нетипових ситуаціях.

3. Доцільне поєднання репродуктивної (відтворювальної) та продуктивної (творчої) пізнавальної діяльності студентів.

4. Здійснення індівідуально-дифреренційованого та особистоорієнтованого підходів шляхом побудови освітнього процесу, в якому організація взаємодії суб'єктів навчання максимальна орієнтована на їх індивідуальні особливості й забезпечує самореалізацію та саморозвиток студента.

5. Правильно організована педагогічна діяльність: а) взаємозв'язок різних форм освіти й самоосвіти; б) технологічна підготовка викладача; в) поєднання підготовки з фізики з професійно-педагогічною; г) опора на сучасні досягнення психології та педагогіки; д) методичні навички організації самостійної роботи.

6. Оптимальне використання комп'ютера в освітньому процесі.

Висновки. Оскільки пізнавальна самостійність є якістю студента, то доцільно організувати навчання так, щоб у процесі діяльності розвивалася пізнавальна самостійності, що приводить до формування цієї якості студента і переведення його з фіксованого рівня на вищий. 
Теоретичний і практичний матеріал вимагає подальшого вивчення. Розвиток і поглиблення проблеми можуть бути пов'язані з плануванням спільної діяльності викладача та студентів для досягнення найбільшого ефекту в розвитку їхньої пізнавальної самостійності.

\section{Література}

1.Данилов М.А. Теоретические основы обучения и проблемы воспитания познавательной активности и самостоятельности учащихся // Учёные записки. Казань. Изд-во Каз. гос. пед ин-та, 1972. Вып. 102. Вопросы воспитания познавательной активности и самостоятельности школьников С. 3-23. Прогресс,

2.Платонов К. К. Краткий словарь системы психологических понятий. М.:

3.Семанов Г.П. Создание благоприятных условий для активной самостоятельной работы студентов-первокурсников // Современные проблемы научной организации учебного процесса в высшей школе. - Калининград: Изд-во КГУ, 1974. - С. 3-27.

\section{References}

1.Danylov M.A. Teoretycheskye osnovы obuchenyia y problemb vospytanyia poznavatelnoi aktyvnosty y samostoiatelnosty uchashchykhsia // Uchënыe zapysky. Kazan. Yzd-vo Kaz. hos. ped yn-ta, 1972. Vыр. 102. Voprosы vospytanyia poznavatelnoi aktyvnosty y samostoiatelnosty shkolnykov S. 3-23. Prohress,

2.Platonov K. K. Kratkyi slovar systemb psykholohycheskykh poniatyi. M.:

3.Semanov H.P. Sozdanye blahopryiatnokh uslovyi dlia aktyvnoi samostoiaᄀtelnoi rabotb studentov-pervokursnykov // Sovremennыe problemы naרuchnoi orhanyzatsyy uchebnoho protsessa v vыsshei shkole. - Kalynynhrad: Yzdvo KHU, 1974. - S. 3-27.

\section{АНОТАЦІЯ}

У пропонованій статmі проаналізовано та уточнено поняття “пізнавальна самостійність студента", охарактеризована ї структура. Визначенні організаційно-педагогічні умови ефективного фрормування пізнавальної самостійності студентів та чинники, під впливом яких вона здійснюється.

Ключові слова: самостійність, пізнання, пізнавальна самостійність студента, структура пізнавальної самостійності, організаційно-педагогічні умови ефрективного розвитку пізнавальної самостійності. 